\title{
Women as Knowledge Workers: From the Telegraph to the Computer
}

\author{
Alison Adam \\ School of English, Sociology, Politics and Contemporary History \\ University of Salford
}

\section{Introduction}

It is tempting to regard the 'knowledge economy' and the role of 'knowledge worker' as recent phenomena predicated on the introduction, and widespread use of electronic information and communications technologies. However, in this chapter, I look to the long history of knowledge work in information and communications technologies such as the telephone, telegraph and computer, arguing that women's work in these industries was vital in shaping modern bureaucratic forms of organization and in rehearsing and affirming conceptions of masculinity and femininity in relation to the use of technology. Studying the development of work in relation to such technologies shows there is continuity in what may be designated knowledge work, at least from the development of the telegraph until the present day, and continuity in the ways that women's skills were valued, or denigrated, in working with these technologies. The history of women's work in telephony, telegraphy and the computer industry demonstrates ways in which women's labour was crucial to the organization of work, the transition to automation and the facilitation of information communication, thus sowing the seeds for modern conceptions of information processing and knowledge work. Although this often receives scant acknowledgement, women played a pivotal part in creating and defining modern technological roles. In this chapter I explore some of the ways in which women contributed to the making of the knowledge worker in the telephone, telegraph and early computing industries whilst struggling with their marginal status in relation to information and communications technologies. 
The invisibility of women's work and women's contribution is a recurrent theme. Recovering women's history (Rowbotham 1977) continues to be a major vector in feminist scholarship. In the making of technical work and knowledge, i.e. knowledge work, such invisibility is played out in particular ways where ambivalence towards women's roles in regard to technical knowledge is revealed and their continued 'blue collar' status serves to underline a difficult relationship with craft unions and the technical roles they help to create. There is a tension here in that women's skills and qualities were clearly not ignored, rather they were often debated in detail and sometimes valued in particular, yet circumscribed, ways as discussions in the technical telegraph press in the nineteenth century reveal (Jepsen 2000). However, the threat the discussion of women's technical skills was often framed against the threat they posed to men's labour and, ultimately, the moral order of society where 'good' women are not to be present on their own in public spaces with all the worldly knowledge this might entail. For instance, Stubbs (2003, 96) argues that the considerable attention paid to women telegraph operators in the telegraph press can be seen, at least in part, as a response to a 'perceived crisis of feminization' in the telegraph industry. At the same time, women's contribution to the making of knowledge and the professional role of knowledge worker was minimized to the extent that it was often rendered invisible. As I describe below this happens in relation to women's work in telegraph and telephone operating (Lipartito 1994), in women's work in early computing (Grier 2005: Light 1999) and in women working in the contemporary IT industry (Woodfield 2002).

\section{Knowledge Work and Technical Skills}

The development of knowledge work through information and communication technologies (including 'old' ones such as the telegraph) has a considerable bearing on what is to count as knowledge, at least those types of knowledge deemed technical. Technical skill or mastery, in other words the situated, embodied skill of using technical knowledge is an important ingredient of what is considered to be knowledge. As researchers (notably Cockburn (1983, 1985) and Wajcman (1991)) have argued, technical skill and masculinity are mutually constitutive. Technical skill is an important part of what it is to be a man; similarly technical skills are defined as 
the skills that men have. The very language of 'mastery' betrays the gendered nature of skill.

Historically, women's technical knowledge is often regarded as necessarily deficient. As Marvin $(1988,23)$ argues there is a moral dimension in that a 'good' woman should not be seen as displaying technical skill. In relation to professional journals in telegraphy and telephony, women were regarded as ignorant and unable to learn from their mistakes and requiring of masculine, chivalrous protection. 'Beneath this habit of indulgence was the more important and even insistent point that women's use of men's technology would come to no good end.' Although women's supposed communications skills were, in some circumstances, regarded as positive, they could be turned against women. Marvin (ibid.) notes the way that the professional electrical press women were regarded as using the telephone for frivolous conversation, to the extent of parodying stereotypical conversations which betrayed that women did not understand how telephones should be used.

'Women appeared as the parasitic consumers of men's labor in most stories of electrical ignorance. Many of these stories turned on wives or girlfriends instructed to make telephone calls or send telegrams. Predictably, these women failed to understand electrical messages the way their male protectors did, as scarce and expensive commodities.' (Marvin 1988, 24).

Women may be present in occupational roles before these roles are defined as technical, before they become gendered. However when a job acquires a 'technical' designation, at the same time, it often becomes a masculine role with higher status. A job may be defined as low skilled and feminized so that workers may be paid poorly as happened in the telephone industry (Lipartito 1994) and, to a lesser extent, the telegraph industry (Jepsen 2000). Women's skills may be contested, as in the telegraph industry but often women's skill in knowledge work is invisible, as with the 'ENIAC girls', the early women computers who programmed the first US computer, who had considerable knowledge of computer hardware but whose work was not acknowledged as a skilled role (Light 1999). 
Part of the reason for the invisibility of women's knowledge work lies in women's association with the life of the body in caring for bodies, young and old and, in contrast, men's association with the rational, life of the mind (Dalmiya and Alcoff 1993). As Lloyd (1984) argues, the women=irrational, corporeal, passive and man= rational, active and incorporeal equation has an ancient lineage extending at least to Ancient Greece and Plato, further reinforced by Descartes' radical separation of mind and body and the alignment of the body with the non-rational. Lloyd's (1984) 'man of reason' transcends the body to live the life of the mind. Dalmiya and Alcoff (1993) argue that the association of women with different, lesser form of reason is nothing short of epistemic discrimination. Whilst it is beyond the scope of this chapter to offer an extended discussion of feminist epistemology, it is sufficient to note that the work of women often revolves round bodily, concrete, invisible labour producing a type of knowledge regarded as subordinate to mental knowledge. Rose $(1994,40)$ describes women's work as 'compulsory altruism' in caring for bodies, a process which disappears into nature. So the 'life of the mind' rests on an invisible substrate of women's caring, regarded as natural.

Mapping the arguments of feminist epistemologists to the development of masculine and feminine skills in technical knowledge work makes the male association with technical skill understandable. Although part of technical skill is embodied, rather than purely mental, it is a skill of dealing with material objects of technology such as telegraph equipment and computers rather than the skill of dealing with bodies and people. Rose (1994) identifies caring as an important part of women's work. This is seen as natural, part of women's role and not even a skill. In the present context it is the communicative, empathetic part of women's role in looking after bodies and people which is emphasized in the development of information and communications technologies although we should note that there is also a situated, bodily element to women's work in these fields. Note the way that the telephone operator's role demands a level of physical fitness, alertness and dexterity as the operator had to stretch to make multiple connections whilst talking to customers, though the headset, with a caring and empathetic manner.

The skill of the telephone operator and the ENIAC programmer are paradigm examples of 'articulation work'. Hampson and Junor $(2005,166)$ define articulation 
work as 'the often unacknowledged management of awkward intersections among the social worlds of people, technology and organisations.' The concept was originally developed by Strauss (1983) but later authors (Star 1991; Suchman 1994, 1996) have emphasized the importance of articulation work in women's work. Articulation work is the "tacit management of the "fragile social order" and explicitly developing a framework to describe it can help to register activities which might otherwise be invisible' (Hampson and Junor 2005, 167). Articulation work is more than coordination and integration, it involves 'meshing' and holding together many tasks, the 'knitting' together of social worlds (Strauss 1993, 213). Some articulation work is routine, visible and acknowledged, but much is non-routine and invisible. Star (1991, 265-7) notes that this relates to women's work, arguing that it is invisible to the point of being 'deleted.' Suchman's $(1994,13)$ example of document management on a law firm shows that the predominantly male lawyers regarded the work of coding documents (largely done by women) as 'mindless labor' and, therefore, potentially to be automated or outsourced. However her empirical research uncovered the document management process to be extremely complex, requiring considerable judgement and knowledge requiring many 'artful integrations' (Suchman 1994, 16). Such 'artful integrations' are abundant, yet largely invisible, in the work of women telephone, telegraph and early computer operators. If not regarded as actually 'mindless' it is not seen as technical skill, rather it is regarded as a bedrock upon which male, technical skill is built.

\section{Skills, Boundaries and the Moral Order}

There is considerable ambivalence and redefinition of what counts as skilled at different times. Women are regarded as skilled, indeed as having special skills by dint of their gender, but their skills are circumscribed and they do not gain advantage, in pay and conditions, from having such skills (Lipartito 1994: Woodfield 2002). Rehearsing and comparing definitions of male and female skills is a way of defining a moral order, delimiting appropriate masculine and feminine behaviour and roles within the workplace. The moral order was not necessarily regarded as fixed but what is consistent is that contradictory behaviour is tolerated in men, less so if it is displayed by women. Men's reputations do not suffer from the negative attributions. Less than good behaviour in men is tolerated whilst in women, it is regarded as 
potentially dangerous and signalling a potential breakdown in the moral order. For instance, an appropriate role for men was often seen as that of the 'chivalrous knight' (Marvin 1988, Stubbs 2003) but this sits alongside the view that men could be unruly and lack concentration and therefore would be less suitable for some types of work in the electrical communications industry. Women could be seen as docile, cooperative and communicative or alternatively as error prone and distracting and perhaps, morally dangerous in their appearance in public places where women were not often present (Jepsen 2000).

'Part of the strategy of male telegraphers, in response to Western Union's attempts to feminize the industry, involved romanticizing the role of the male operator as a kind of moral hero, a 'knight of the key' whilst denigrating women's skills and assuming that they would damage equipment and distract male operators. In particular, the ambiguity of the women telegrapher's role was evident as she exemplified a woman working freely in a public space at a time when women were expected to remain in the private sphere of the home.' (Stubbs 2003, 97)

The moral ambiguity of the woman telegrapher's role demonstrates this. Jepsen $(2000,112)$ notes the response of male telegraphers, in the $1870 \mathrm{~s}$, to the perceived encroachment of women operators as signalling a breakdown in the moral fibre of society, the end of marriage and signalling the onset of barbarous life. Hall (1993) argues that it was the unsupervised sexuality of women which was seen as problematic. On one hand this meant that women telegraph operators might be available for romantic interactions but also that they were more worldly than those women who stayed at home, indicating that theirs was a type of knowledge not seen as appropriate for a 'good woman' and that they might be morally corrupted by working as telegraph operators.

Jepsen $(2000,113)$ argues that the morally ambiguous nature of women's telegraph work was reinforced by the location of the telegraph office which was usually in or near the railway station. Railway stations were, indeed still are, ambiguous places, where all sorts of members of society come into contact from daily commuters and families to 'common workmen, drunkards, gamblers, and prostitutes' (Jepsen 2000, 113). 'Red light' districts were often located near rail stations and women 
telegraphers were seen as in danger from moral corruption just by knowing this and the kinds of activities associated with the red light district. Concerns with sexual ambiguities raised in relation to women telegraphers were reinforced by the way that the telegraph, not just offered the chance for some women, at least, to earn enough to live independently, but also for women to communicate with anyone they wished to contact without their families being able to exercise control.

Women telegraphers, to a greater or lesser extent, lived on the edge of society's boundaries and were treated as morally ambiguous because of this. Douglas's (1966) classic anthropological work on boundaries and margins emphasizes that we make boundaries, or frontiers, to create social order. In making social order we are not just condemning disorder - we are recognizing that disorder is both dangerous and, at the same time, potent (Douglas 1996, 94). Those whose position in society is marginal, in other words who live on a social, moral or geographic boundary, may enjoy a status which may be indefinable and even dangerous, but powerful at the same time. Hence, to be in a marginal condition is to be in a dangerous condition but it is also a source of power and knowledge. The woman telegrapher, in her workplace role, in a public setting, often within or near a railway station with all the morally dubious connotations that attached to such a place, communicating with strangers at work or through the wires and with her knowledge of 'worldly matters' was powerful, marginal and threatening.

This is further reinforced when considering women working on the US frontier. In US culture, the myth of the Western frontier has been immensely potent. Kramer and Kramarae (1997) claim that the story of the frontier spirit is essentially masculine, adventurous, dangerous, violent and frequently heroic. They argue that frontier women are often portrayed in stereotypical ways e.g. 'Calamity Janes' or 'Brave Pioneer Mothers' without an acknowledgment of the multifaceted ways that they contributed toward making and organizing new societies. Celebrating the frontier spirit may involve overestimating masculine values whilst underestimating or ignoring women's contributions. Special rules apply at the frontier; law and order and morality may be different at a geographic location remote from the rest of social life (Slotkin 1993). The frontier is also a place where women's skilled use of the telegraph 
as an information and communications technology is an important part of their abilities to act effectively outside the norms of expected behaviour.

Hence women's contribution to frontier life was not always ignored. Stories of women telegraphers on the Western frontier demonstrates that women, at least to some extent, could attain special powers and knowledge by dint of their marginal status on that special boundary, the frontier.

\section{The Telegraph and Telephone Industries}

Standage (1998) aptly describes the telegraph as 'The Victorian Internet'. In terms of the speeding up of communications it undoubtedly had an effect beyond that of the Internet. It is important not to overstate the democratic potential of new information and communications technologies (Ess 1996; Winner 1997), nevertheless there is a sense in which the advent of successive communications technologies not only speeds up the transfer of information but also makes access to information transfer available to more people. This is seen at its most dramatic with the telegraph. In medieval times, in order to send a communication to someone many hundreds of miles distant one had to be fairly rich and powerful, first of all to have the level of literacy to write a letter, but also to buy the time of a messenger. The advent of the penny post in the UK in the 1840s, and similar cheap and organized mail systems elsewhere, not only speeded up communication, but also by its cheapness made communications much more widely accessible. Similarly the telegraph network, which linked many parts of the globe by the end of the 1870 s, was not only accessible to anyone who lived near a telegraph station or office with the means to pay for a telegram and a sufficient level of literacy to read and write messages, but also was the cause of the most dramatic collapse of communication time in our history ever experienced, as messages which previously took weeks or months could be at their destinations in a matter of hours (Standage 1998).

Importantly, we should see innovations such as the telegraph and telephone network in terms of innovations of work as much as technology. A significant industry developed around the telegraph. Standage $(1998,154)$ describes the telegraph as the 'handmaiden of commerce', noting the way in which the telegraph stimulated and 
accelerated commercial transactions. By the 1870 s, when markets were published daily customers could be contacted by telegram. The seeds of globalization were sown with the telegraph as it became much easier to communicate with geographically distant suppliers. The railway and the accompanying telegraph network were crucial to economic success, stimulating the growth of new commercial organizations whose business was based on the ease of communication afford by the telegraph. By analogy with the 'dot coms' of the Internet age these were businesses that one might designate 'dot dash' coms. The role of the telegraph was not confined to commerce. It became a significant military technology. The telegraph (and accompanying railway) significantly shaped the North's victory in the American Civil War (Jepsen 2000).

Not surprisingly, the telegraph became an exceedingly profitable industry in its own right and thousands of operators were employed. Yet women's role in the telegraph industry is often not acknowledged. Jepsen (2000) argues that it was not just a question of male-dominated historiography, although that is certainly part of the story. More importantly this was due to the unique position of telegraphers in the work place in the nineteenth century. "They were "information workers" and "technicians" before these terms existed. Male and female telegraph operators alike were regarded with awe by a public that little understood the workings of the "lightning machine" that sent messages from place to place almost instantaneously.' (Jepsen 2000, 85). This signals part of the problem in considering such work as 'knowledge work' and the ambivalence with which the role was treated, at the time and in later histories. Jepsen argues that telegraph operators were regarded with some respect and were regarded as having specialist knowledge. Yet, at the same time, women were expected to work for low pay and were often segregated form the public in 'back room' operations and the special skills of the telegraph worker (as a woman worker) were downplayed.

Women's skills in telegraphy and telephony were treated ambivalently in relation to contemporary discourse concerning women joining the US National Telegraph Union (NTU). As Cockburn $(1983,1985)$ argues the history of craft trade unions has often formed a vehicle for men to control a craft occupation to the exclusion of women, Telegraphy was no exception, with women only admitted in 1865 (Jepsen 2000). Discussion in the pages of NTU's journal gives traditional arguments as to women's 
supposed error prone nature, the problem that women would work for lower wages than men would accept, thereby undercutting and excluding men, and the question of whether a 'rough' telegraph office was an appropriate place for a lady to work (Jepsen 2000).

However, others saw women as potentially skilled telegraph workers. A contemporary publication on types of employment available to women, The Employment of Women (Penny 1863, 100-101) suggests that women telegraphers were better than men because of their undivided attention to their work. If their lack of business knowledge meant that they sometimes made mistakes in messages, a short course in business terminology was all that was needed to remedy this. Women were seen as reliable, with more concentration and quicker than men. Their cheaper wages made them attractive employees for the telegraph industry. Office work, including typing, telegraphy and telephone operating attracted many middle class women into the workplace for the first time. Interestingly, as Baker (1964, 67) notes, although significant numbers of women were employed in telegraphy, it never became the 'women's occupation' that telephony created. It is difficult to explain this in any objective way and this serves to reinforce that that there is no rational way to decide whether one type of work is deemed technical while another type is seen as not technical (less difficult, less skilled).

Telephony (Baker 1964) was seen as a simpler, narrower form of work where women were seen to be suitable as they were docile and could be employed on low wages. A clue to the early reason why women were seen as better telephone operators than men is given by Baker's $(1964,68)$ description of crude telephone switchboards which were built on the plan of telegraph switchboards shortly after the telephone became commercially available. Initially staffed by boys they 'soon became so impudent, noisy and inattentive that girls were taken on to replace them.' (Baker 1964, 68) This confirms the myth of women as docile, yet good verbal communicators, which was seen as more important in telephone industry, where a crucial part of the role involved operators speaking to customers. Although telephone companies did not pay women good wages, they nevertheless saw the virtue of attracting 'well bred women' by offering comfortable rest rooms and additional benefits such as lectures, prizes, circulating libraries and even a women's athletic club (Baker 1964, 70). Telephone 
companies were hopeful that their employment of 'well bred' women of a docile nature would ensure cheap labour and easy labour relations. Yet women telephone operators in Boston organized their own trade union and organized large scale strikes in 1919 and 1923. The 1919 strike paralyzed the telephone service in New England for almost a week winning a favourable settlement for its members. This achievement was substantial given that the members were mostly young, with little experience of labour politics and facing considerable opposition as women working for a living wage (Norwood 1990)

Lipartito's (1994) description of the role of the telephone operator, making and switching multiple connections and keeping track of several complex transactions at the same time with clear verbal communication paints a picture of a role which is akin to the contemporary air traffic controller in its attention to details, communications skills and ability to keep track of multiple complex paths. Considerable articulation work was required to undertake this complex labour process where operators had to stretch to right or left to reach all the subscriber jacks in the exchange and had to learn how to handle several connections at one time.. 'Manual switching had a gender, and here we can see how cultural categories combined with strategy and technology to form a labor process. The social construction of telephone technology created an entirely new group of skilled workers - telephone operators.' (Lipartito 1994, 1082)

\section{Working in the Telegraph Office}

Cockburn (1983, 1985) and Wajcman (1990) argue that definitions of technical skill are strongly linked to conceptions of masculinity and femininity. Occupations that become defined as technically skilled are usually seen as male jobs and they attract higher status and financial reward. By contrast, a job seen as less skilled attracts less status and pay and may become a woman's job. When an occupation role is new, and has not become segregated along gender lines it may be possible for women to work in areas that may become relatively closed to them at a later stage when the role becomes seen as masculine. This does not mean, however that new roles are havens of equal treatment for women. Even if they are present at the early stages of a role which later becomes a male job, they are still likely to be marginalized and have their skills underplayed. Occasionally one sees arguments about the computer industry being 
more open to women as there is less time for the IT industry to develop as an entrenched masculine sphere of work, although this is something of a myth (Axios 2002). As Light (1999) argues, in terms of the very first women programmers, the 'ENIAC girls', their considerable skills were undervalued and the girls were rendered invisible in any official reports of ENIAC work.

Telegraphy was seen as a skilled, masculine occupation, although it was a technical job, not on a par with professional jobs such the law or the clergy. It was part of what Light (1999) and Shapin (1988) have described a 'back room' or 'blue collar' science. Possibly because of its newness, women had managed to gain a foothold and were often paid relatively well compared to other working class women. Therefore women telegraphers were in a strange and rather marginal position and it is not surprising that controversy raged in the pages of the telegraphy trade press, as to women's skill or lack of it (Smith 1865).

The Employment of Women (Penny 1863, 101) saw the ideal working situation as one where '...the arrangement would be to have a clerk to receive and deliver communications, and the corps of operators and writers, composed exclusively of females, in an adjoining or upper room, apart from public inspection.' In such larger telegraph offices women were kept apart from the public and there seems to be some suggestion of preserving modesty. But at the same time this had the effect of permitting the women operators less opportunity of interacting with the public and using the technology in more diverse ways and of using their social or managerial skills in relation to the technology. Larger offices would have been a luxury available in cities and bigger towns; clearly many telegraph offices were staffed by a single operator, particularly in remote areas of the USA's Western frontier where the telegraph line followed the railway line (Jepsen 2000)

Such offices were effectively run as small businesses. Women would have to repair and maintain telegraphic equipment; there was no one else to do it. A fictional tale on the American frontier of a woman telegraphic operator reveals the type of technological heroism normally attached to men. Recalling that the telegraph follows the railroad, 'Carrie the Telegraph Girl' (Crawford 1891) bravely climbs into the loft when she sees bandits approaching the telegraph station to apprehend the next train, 
breaks the wires, and by striking the ends together sends a telegraph message to the next station to summon the sheriff with a posse.

But the heroic tale of the telegraph girl on the frontier is a far cry from the heroine of Henry James' In the Cage (James 1922). Although a work of fiction, In the Cage points up the tensions, some of which are acute, in the women telegrapher's role. She is skilled knowledgeable and detailed in her work; indeed the denouement of the book relies on her professional skills. This woman has plenty of knowledgeable skill in understanding and weighing up her clients. However it is this very knowledge which keeps her 'In the Cage'. Acutely aware of her lowly station in life and the impossibility of her ever transcending it, she nevertheless falls for the dashing Captain Everard, she is duty bound to tell him that she recalls vital numbers from a telegraph message he had not kept which leads to him marrying the rich lady. Her special skill, in fact, means that she remains 'in the Cage' rather than having a chance with Captain Everard.

A number of themes from In the Cage signal the beginnings of women's roles as knowledge workers and foretell the tribulations that women would have as knowledge workers in the development of the information industry in the twentieth century. The cage that contains the narrator (we never know her name) is a physical cage but it is also a virtual cage in several senses. It is the cage which keeps her in her working class, blue collar, behind the scenes situation. But is also the cage of bureaucratization and rationalisation of work. Weber's concept of the 'iron cage' derives from Parsons' translation of his work (Weber 1930) and so is a term unlikely to have been familiar to James in this context. Nevertheless the telegrapher's iron cage is as much a cage of modern bureaucratic organization as it is cage which keeps her in her station in life part of what the iron cage does is keep the workers working. The narrator leaves her cage at crucial points when she walks along the street talking to Everard almost as an equal, revealing something of her feelings, but she knows she must return to her allotted station.

These accounts are fictional, yet they illustrate the disparate lives that women may lead as knowledge workers. Women have a curious status in the telegraph industryoften at the boundaries or margins. They enjoy a level of independence not 
necessarily available to other women but at the same time they are firmly of a 'blue collar' status. They are caged in the large city telegraph office although this separation from the public can necessarily never be complete. Although the telephone operator had to interact with the public, the almost complete feminization of the role, coupled with the physical separation from the public meant that this role was seen as less threatening to masculine status and the moral order.

\section{When Computers Were Women}

Grier (2005) notes that human computers have been used for making manual calculations at least since the seventeenth century. Much early work involved astronomical calculations, useful for navigation, commerce and ballistics. Later work included the manual calculation of mathematical tables, still used in education but supplanted by calculators and computers for practical purposes. In a world where our reliance on automatic calculation is almost complete the difficulties of constructing mathematical tables accurately, and the reliance on accurate calculation (bearing in mind that the effects of an error would quickly be compounded in a mathematical table) has largely sunk out of sight. Nevertheless this work relied on a large quantity of skilled labour, much of it women's.

Career options for women may have been limited in the mid nineteenth and early twentieth century, but they were especially limited in scientific and technical domains. Mathematics was just about the only scientific area where women could contribute. If a woman went into a technical career after college or university education it was often into the so- called 'subprofessional' blue collar backroom science of calculation. This mirrors the argument above of women as 'back room' staff in the telegraph and telephone industries. No matter how skilled the work involved women's labour remains the substrate on which masculine technical skill is built.

When heroic tales of scientific discovery or invention of computers are told, the women's labour on which it may have rested is rendered invisible. Women are collectively herded into a 'cage' as in the Henry James novel often only assigned a collective naming which emphasises their junior status e.g. as in 'Pickering's Harem' 
in the US Naval Observatory (Grier 2005) or as in the 'ENIAC Girls' (Light 1999) who were the operators and programmers of the first US computer. The invisibility and interchangeability of women is seen in the way that the scientist Cecil Powell requested, apparently without irony, 'three more microscopes and three more girls' in order to continue with important calculations.

This lumping together, rendering invisible, making part of a herd and juniorizing continued in the IT industry almost to the present day. On a personal note, my first job in the late 1970s involved writing computer programs for batch mainframes. One wrote out the program on special squared paper. This was handed in at a hatch at the 'punch room' where a day or so later a pile of punched cards with the squared paper wrapped round the cards that had been produced by one of the 'punch girls' appeared. Of course, one never got to talk to the punch girls and they were never in a position to understand or interpret the cards they punched. However, Christine, one of the systems programmers (regarded as a very technical and knowledgeable professional job, but not a managerial role) had apparently worked her way up from being a punch girl. She was treated with a measure of respect - as a kind of honorary man although she was never given a management role.

Pickering's Harem, the ENIAC girls and even my punch girls were paid poorly. The salary offered to Harvard computers was 'half the prevailing work for calculation' (Greir 2005, 83). The Director of the Naval Observatory in Washington observed that the Harvard computers can be got to work for next to nothing, thus continuing the tradition of deliberately poor pay.

\section{Women in the Contemporary IT Industry- a contemporary story of hybrid skills.}

Drawing on some of the salient points from the discussion of women in the telegraph industry and women as early computers, thinking of them, in both cases, as knowledge workers, there are parallels with the development of the knowledge worker role in the contemporary IT industry. In particular, I wish to compare attitudes towards women's skills and how these are incorporated into the role of the knowledge worker. So far, I have described ambivalence in relation to women's technical skills. Contemporary commentators (in all three industries) did recognise the role of what 
they defined as non-technical, specifically communications skills in combination with so-called technical skills. They also believed that women possessed such skills in greater quantities than do men. However, there is a distinct sense in which the combination of technical and traditional feminine communications skills did not always work towards women's benefit. Rather such 'hybridity' (Woodfield 2002) whilst being seen as desirable, serves to reinforce women's junior and often marginal status.

Woodfield $(2002,120)$ describes the way in which women's supposedly valued communications skills are seen as vital to the transformation of modern technically infused organization "centred on the attempt to provide a more "professional" service to the user community.' In her empirical research in two IT organizations the desire for workers with hybrid communication and technical skills and the belief that women are the best hybrids were often expressed. However, the positive aspects of women's hybrid skills were often ill-defined as expressed within a discourse that she (2002, 125) identifies as 'She's a nice woman.. but sometimes I worry if that's enough to warrant her being here.' This translates into a view of women's abilities rarely being seen as at the centre of skilled information systems design.

In contrast, a view prevailed that communication skills when found in men were much more important to the design of information systems. Not surprisingly, Woodfield's (2002) women interviewees felt under-utilized and there was little evidence that women's widely touted superior communication skills were being brought to positive effect on labour processes. Communication skills were regarded as a 'normal' feminine attribute and ignored but when such skills were seen in men they were noted and valued. Woodfield $(2002,133-4)$ concludes that: '..the degree to which social skills are defined and assessed is highly dependent upon a worker's gender... it is not so much the level of skill itself that is being judged but the cultural skills of the worker possessing the skill.'

\section{Conclusion}

The development of women's roles in information and communications technologies - the telegraph, telephone, early and later computing - all show women making a 
crucial contribution to the development of knowledge work and the organization of work in the new communications technologies. Yet there was a continued struggle against the view that their jobs were lacking in technical skill. The many 'artful integrations' (Suchman 1994) involved in their work remain invisible. It is striking that, all the way through the history of women working in electrical communication their communications skills are seen as desirable but these skills rarely work positively for women. Despite the way that women in the telegraph industry were charged more or less explicitly with shaking the moral order in their work in doubtful public places with the knowledge that this brings, theirs was a key role in opening the workplace to women. Women's relationship to work and presence in public spaces has changed to the extent that, at least in Western countries, we no longer see expressions about the degradation of the moral order which women's work will incur. However, women's marginality in relation to work in information communications technologies is expressed in more subtle ways. Woodfield (2002) notes the way that a respondent wondered why a woman was in the organization; women themselves noted that their work was under-utilized. Adam et al (2006) describe an empirical study of women in IT where women discuss ways in which women try to neutralize their gender by modifying their dress and behaviour, conscious of their marginality and the need not to stand out as a women. This suggests that women's feelings of marginality are expressed in different ways and even in contemporary times a feel of not belonging is still problematic. The tension between women working in technical roles, struggling to have these valued and the marginality that this entails is a continuing historical thread.

\section{References}

Adam, A. Griffiths, M., Keogh, C., Moore, K., Richardson, H. and Tattersall, A. (2006) 'Being an it IT' - Gendered Identities in the IT Workplace, European Journal of Information Systems, 15 (4): 368-378.

Axios (200) Lack of Women Does not Compute, Available online http:/www.axiossystems.com/six/en/corporate/news/detail.php/86 (accessed Feb 12th 2009).

Baker, E.F. (1964) Technology and Women's Work. Columbia University Press: New York and London. 
Blok, A. and Downey, G. (eds) (2003) Uncovering Labor in Information Revolutions, International Review of Social History Supplement 11, Cambridge University press, Cambridge UK.

Cockburn, C. (1983) Brothers: Male Dominance and Technological Change. Pluto: London.

Cockburn, C. (1985) Machinery of Dominance: Women, Men and Technical KnowHow. Pluto: London.

Crawford, J. (1891) Carrie the Telegraph Girl: A Romance of the Cherokee Strip, Parts 1, 1 and 3. Burnett County Sentinel, June 20, Available online http://www.mindspring.com/ tjepsen/Teleg.html (accessed March, 21, 2003).

Dalmiya, V. and Alcoff, L. (1993) Are 'old wives' tales' justified? In L. Alcoff and E. Potter (eds.) Feminist Epistemologies, Routledge, New York and London, 217-244.

Douglas, M. (1966) Purity and Danger: An Analysis of the Concepts of Pollution and Taboo. Ark, London and New York.

C. Ess, "The Political Computer: Democracy, CMC, and Habermas," Philosophical Perspectives on Computer-Mediated Communication, C. Ess, ed., SUNY Press, Albany, NY, 1996, 197-230.

Grier, D.A. (2005) When Computers Were Human. Princeton University Press: Princeton and Oxford.

Hall, J. D. (1993) O. Delight Smith's progressive era: Labor, feminism and reform in the urban south, in N.A. Hewitt and S. Lebsock (eds.) Visible Women: New Essays on American Activism, University of Illinois Press: Urbana Champaign IL, 166-198.

Hampson, I. and Junor, A. (2005) Invisible work, invisible skills: interactive customer service as articulation work, New Technology, Work and Employment, 20(2): 166-181.

James, H. (1922) In the Cage, in What Maisie Knew, In the Cage, The Pupil. Macmillan, London, 323-449.

Jepsen, T.C. (2000) My Sisters Telegraphic: Women in the Telegraph Office. Ohio University Press: Athens $\mathrm{OH}$.

Kramer, J. and Kramarae, C. (1997) Gendered Ethics on the Internet, in J. Makau and R. Arnett (eds.) Communication Ethics in an Age of Diversity, University of Illinois Press, Urbana, IL and Chicago, IL, 226-243.

Lipartito, K. (1994) When Women Were Switches: Technology, Work and Gender in the Telephone Industry, 1890-1920, American Historical Review, 99(4), 1076-1111. 
Light, J.S. (1999) When Computers Were Women, Technology and Culture, 40 (3 ), 455-483.

Lloyd, G. (1984) The Man of Reason: 'Male' and 'Female' in Western Philosophy University of Minnesota Press, Minneapolis MINN.

Marvin, C. (1988) When Old Technologies Were New: Thinking About Electrical Communication in the Late Nineteenth Century. Oxford University Press: New York and Oxford.

Norwood, S.H. (1990) Labor's Flaming Youth: Telephone Operators and Worker Militancy. University of Illinois Press: Urbana and Chicago IL.

Penny, V. (1863) The Employment of Women: a Cyclopedia of Women's Work. Walker, Wise \& Co: Boston MA.

Rakow, L.F. (1992) Gender on the Line: Women, the Telephone, and Community Life. University of Illinois Press: Urbana and Chicago IL.

Rose, H. (1994) Love, Power and Knowledge: Towards a Feminist Transformation of the Sciences. Polity, Cambridge.

Rowbotham, S. (1977) Hidden from History: 300 Years of Women's Oppression and the Fight Against it. Pluto, London.

Shapin, S. (1988) The House of Experiment in Seventeenth-Century England, Isis 79, 373-403.

Slotkin, R. (1973) Regeneration Through Violence: The Mythology of the American Frontier, 1600-1860, Wesleyan University Press, Middletown CT.

Smith, L. (1865) Lady Operators, The Telegrapher, Feb 27, 58. Online available at http://www.mindspring.com/ tjepsen/ladyopr.html )accessed March 12th 2001).

Standage, T. (1998) The Victorian Internet. Phoenix: London.

Star, S.L. (1991) The sociology of the invisible: the primacy of work in the writings of Anselm Strauss, in D. Maines (ed.) Social Organization and Social Process: Essays in Honour of Anselm Strauss. Aldine De Guyter, New York, 265-284.

Strauss, A. (1985) Work and the division of labour, The Sociological Quarterly, 26 (1), 1-19.

Stubbs, K. (2003) Telegraphy's Corporeal Fictions in. L. Gitelman and G.B. Pingree (eds.) New Media: 1740-1915. MIT Press, Cambridge MA, 91-111.

Strauss, A. (1993) Continual Permutations of Action. Aldine De Guyter, New York.

Suchman, L. (1994) Supporting articulation work: Aspects of a feminist practice of technology production, in A. Adam, J. Emms, E. Green and J. Owen (eds.) Women, 
Work and Computerization: Breaking Old Boundaries - Building New Forms. Elsevier, Amsterdam, 7-21.

Suchman, L. (1996) Supporting articulation work, in R. Kling (ed.) Computerization and Controversy, $2^{\text {nd }}$ edition, Academic Press, San Diego CA, 407-423.

Wajcman, J. (1990)Feminism Confronts Technology. Polity, Cambridge UK.

Weber, M. (1930) The Protestant Ethic and the Spirit of Capitalism. Translated by T. Parsons. Allen \& Unwin, London.

Woodfield, R. (2002) Woman and information systems development: Not just a pretty (inter)face? Information Technology \& People, 15 (2), 119-138.

Winner, L. (1997) Cyberlibertarian Myths and the Prospect for Community, ACM Computers and Society, 27 (3), 14-19. 